\title{
A Multilingual Monologue: Alexander Lenard's Self-Translated Autobiography in Three Languages
}

\section{Helga Lénárt-Cheng}

\begin{abstract}
The paper investigates the question of self-translation in the work of Alexander Lenard (Lénárd Sándor). Lenard, a polyglot writer and translator, rewrote his autobiography three times, in three different languages (in German, English, and Hungarian). This process of self-translation created a fascinating web of autobiographical texts, which invite a multiscopic reading. Following in the footsteps of 18 th century parodists, Lenard challenges a great number of protocols associated with life-writing. The most important among these is the authority of the proper name as a guarantee of autobiographical authenticity. To challenge the authority of the proper name Lenard purposely multiplies his own authorial identities, for example by claiming that "A. L. is only a pseudonym." Thus, the word 'self-plagiarism' acquires in Lenard's case a double meaning, implying both that the author plagiarizes his own text and that he plagiarizes his own self. The paper explains why existing theories of self-translation cannot be applied to Lenard's texts, and why his unique case can enrich future studies of this topic.
\end{abstract}

Keywords: Alexander Lenard, Lénárd Sándor, Self-Translation, Autobiography, Proper Names

Biography: Helga Lénárt-Cheng studied French and German at JATE and ELTE in Hungary, and she received her $\mathrm{PhD}$ in Comparative Literature from Harvard University. Since 2008 she has been on the faculty of the Department of Modern Languages at Saint Mary's College of California. Her research interests include the philosophical tradition of phenomenological hermeneutics, philosophies of subjectivity, various genres of life-writing (autobiographies, memoirs, diaries, blogs, etc.) and theories of utopia. She has just completed a monograph on Alexander Lenard, and she is working on her book about the political utopias associated with the sharing of life stories.

\section{The Lack of an Authoritative [Auto]biography for Lenard}

Alexander Lenard (1910-1972) once wrote: "Blessed those whose lives could never become a novel, for theirs is the Kingdom of Heaven [sic]" (1965: 86) ['Boldogok azok, akiknek életéböl nem lehet regényt írni, mert övék a mennyek országa!' (1973, Valley: 79)]—a bittersweet statement coming from someone whose life was the epitome of a suspense novel. Lenard, a writer best known for his best-selling translation of Winnie the Pooh into Latin, was born into a Hungarian family with German-Jewish origins. Although he only spent the first eight years of his life in Hungary, Lenard never lost the connection to his childhood language and culture. After the First World War his family moved to Austria, where Lenard completed medical school while also writing poetry and practicing translation. Growing Nazi pressure 
Lénárt-Cheng, Helga. "A Multilingual Monologue: Alexander Lenard's Self-Translated Autobiography in Three Languages." Hungarian Cultural Studies. e-Journal of the American Hungarian Educators Association, Volume 7 (2014): http://ahea.pitt.edu DOI: 10.5195/ahea.2014.3

forced him to flee to Rome in 1938. For the next fourteen years Lenard was a guest of the Eternal City, first as a starving, illegal immigrant, later as a family man with a series of temporary jobs. According to his own account, he survived the war by hiding in the Biblioteca Nazionale and the Vatican Library, where he spent countless hours reading medieval manuscripts and studying languages. During these years he also wrote medical treatises, dissertations, and translationsoften under the name of others.

Following the war Lenard's immigration status in Italy was legalized, which allowed him to become a doctor at the Hungarian Academy of Rome. This position gave him the opportunity to meet other writers, poets and scientists, and he finally began to feel at home in Rome. However, by 1951 Lenard was so worried about the potential outbreak of another World War that he decided to leave Europe and seek refuge in Brazil, where he worked as a doctor in a mine and as a private tutor until he could establish his own medical practice. He chose to settle in a tiny village at the edge of the rainforest, where until his death he lived among the local indios and German settlers. In the 1960s he translated several books into Latin, the most famous being his translation of Winnie Ille Pu, which remained on The New York Times bestseller list for twenty weeks. Although Lenard never again returned to Europe, he did not lose contact with the ideas and people that shaped his worldview. From his "invisible house" in Dona Emma he continued to correspond with a large network of scholars and friends from around the world, while soothing his homesickness with books, gardening and music.

In one of his autobiographies Lenard offers a rather picturesque account of his peripatetic journey:

Shall I enumerate my occupations - as it is polite in an introduction? I was a kitchen boy; I measured blood pressure, going from house to house; I was the doctor of the Hungarian Academy in Rome; I was a beggar; I served as an anthropologist for the American Army, reassembling skeletons from tiny pieces at the foot of Machiavelli's vineyard next to picturesque Mount Vesuvius...In addition, I wrote art history, archeological, and medical dissertations behind the thick brick walls of the Biblioteca Nazionale and the Vatican Library...For a while, I played piano duets with a director of a bank in exchange for dinner, while his cook-who was more sensitive to my situation - stole potatoes for me from his pantry so that I would have something to eat the following day, too. I was the translator of the first postwar congress of dog-breeders. I had many patients: a warden once referred a pickpocket with sciatica to me; this same man in turn recommended me to other thieves and burglars. I treated the varicose veins of a bishop and ordered insoles for the flat feet of a superior when the founding saint of the order wasn't willing to help..."

[Soroljam fel—mint ahogy ez bemutatkozásnál illik—foglalkozásaimat? Voltam kukta, mértem házról házra vérnyomást, voltam a római Magyar Akadémia orvosa, koldultam, a Vezúv festöi táján s Machiavelli szölöhegye tövében mint az amerikai hadsereg antropológusa csontvázakat raktam össze apró darabkákból...Írtam még müvészettörténeti, archeológiai, orvosi disszertációkat a Biblioteca Nazionale öles téglafalai mögött meg a vatikáni könyvtárban...Egy ideig két zongorán játszottam egy bankigazgatóval vacsoráért, s nála megértöbb szakácsnöje krumplit lopott részemre a spájzból, hogy másnap is legyen mit 
Lénárt-Cheng, Helga. "A Multilingual Monologue: Alexander Lenard's Self-Translated Autobiography in Three Languages." Hungarian Cultural Studies. e-Journal of the American Hungarian Educators Association, Volume 7 (2014): http://ahea.pitt.edu DOI: 10.5195/ahea.2014.3

ennem. Én voltam az ebtenyésztők elsö háború utáni kongresszusának forditója. Voltak pácienseim: egy börtönör egyszer elküldött egy isiászban szenvedö zsebtolvajhoz, aki továbbajánlott zsebtolvaj- és betörökörökben. Kezeltem egy püspök visszereit, egy rendfönöknönek lúdtalpbetétet rendeltem, mert a rend alapitója nem volt hajlandó megtenni a boldoggá avatásához szükséges csodát...] (1973: 24-25) [the English translation is mine].

The problem is that to this day there does not exist any monograph or biography of Lenard, but only scattered articles and biographical sketches, so readers form their views on Lenard's life and work solely based on his own autobiographical accounts. ${ }^{1}$ The lack of research on Lenard's life has also contributed to the romanticization of his image as a musical and linguistic genius. Lenard was fluent in a dozen languages and published fiction, poetry, medical treatises, historical cookbooks, and linguistic studies in five languages (Hungarian, German, English, Latin and Italian); he was also a skilled translator and interpreter, a physician, an expert in medical history, and an excellent musician and connoisseur of Bach. His admirers often portray him as an adventurer driven by his quixotic passions, a "Hungarian Albert Schweitzer" living on the edge of the rain forest. Yet, this larger than life portrait is based on scarce evidence, because not only does no biography exist but, in addition, many of Lenard's writings were circulated in small editions only. Thus, most readers can never access his writings in all five languages, let alone trace his publications and adventures in half a dozen countries. In situations where no "definitive" biography exists the role of autobiographical accounts gets inflated, as readers tend to treat the author's memoirs as primary sources of information. Lenard wrote three different autobiographical texts: his Római történetek ['Stories of Rome'] deal mostly with the war years; Egy nap a láthatatlan házban ['A Day in the Invisible House'] describes a day in his life in Brazil; while Völgy a világ végén ['The Valley at the End of the World'] offers his most comprehensive self-portrait. ${ }^{2}$ Lenard himself encouraged his readers to read his autobiographies as factual accounts. He declared: "I have no imagination whatsoever, I can only write down the perfect truth, I stick to the facts" [Képzeletem nincs, csak a szintiszta valóságot vagyok képes leírni, tapadok a tényekhez] (1973, One Day: 660), and on the copyright page he noted: "Characters and events portrayed in this book represent a cross-section of people and happenings I have known throughout my life in Brazil and elsewhere, up to a few years ago. As reflections of my cumulative experience, they are, I hope accurate in essence" (1965).

${ }^{1}$ In 1999 Zsuzsanna Vajdovics founded an online research seminar (http://mek.oszk.hu/kiallitas/lenard/szeminarium/szeminarium.html), and in 2000 she brought back Lenard's Hungarian manuscripts, notes and correspondence to the Petöfi Literary Museum [Petöfi Irodalmi Múzeum] in Budapest. Since then the scholarly interest in Lenard's work has increased. See http://mek.oszk.hu/kiallitas/lenard/indexeng.html

${ }^{2}$ The three texts were published in one volume (along with a few other writings) in 1973 in Hungarian under the title Völgy a világ végén s más történetek [Valley at the End of the World and Other Stories]. Henceforth I will refer to this 1973 edition, marking the page numbers along with the abbreviated titles Valley, One Day, and Rome. English translations from this volume are all mine, except for quotations from Völgy a világ végén [The Valley at the End of the World], which also appeared in 1965 in English in Lenard's own translation under the title The Valley of the Latin Bear. 
Lénárt-Cheng, Helga. "A Multilingual Monologue: Alexander Lenard's Self-Translated Autobiography in Three Languages." Hungarian Cultural Studies. e-Journal of the American Hungarian Educators Association, Volume 7 (2014): http://ahea.pitt.edu DOI: 10.5195/ahea.2014.3

To further prove the truthfulness of his account, Lenard argued counter-intuitively that although the book may be full of contradictions and unbelievable adventures, this in itself is the best proof of its veracity, because reality is always more unpredictable than the logical world of books. And he concluded his account of his life with the following words: "Quod modo proposui non est sententia verumst" ['What I presented here is not just an opinion, it is the truth'] (1973, Valley: 178). However, while claiming absolute truth for his own autobiography, Lenard also made fun of the naïve idea of a "factual" autobiography. He described autobiographies as "mirrors that show an angel even when the devil looks into them" [Tükrök, amelyekböl akkor is angyal néz ki, ha ördög bámul beléjük] (1973, One Day: 660), and he parodied the authority of a "fact-based" literature more generally. Following in the footsteps of eighteenth-century parodists, he used clever rhetorical tricks to convince his readers of the veracity of his story, while also making the artifice obvious. For example, he compares his own adventures to those of Gulliver and swears with Gulliver that everything he says is true, while also reminding his readers that his "oath is only worth as much as that of Lemuel Gulliver" [az esküm csak annyit ér, mint Gulliver Lemuelé] (1973, Rome: 327)—a fictional character. Lenard knows that "in novels readers search for signs of reality, and in reports they look for signs of the imagination" [az olvasó a regénynek mondott írásban a valóságot keresi, a beszámolóban viszont a képzelet nyomait kutatja] (Lenard 1957), so he purposefully blurs the distinction between the two. For example, when editors ask him for permission to add a biographical blurb and a photo to his book jacket, Lenard refuses and pleads: "God save me from putting my photo on the cover! ... please make sure that they do not put me on exhibition" [Isten ments hogy rákerüljön a fényképem! ... eszközölje ki, hogy ne tegyenek a kirakatba] (1965b/6/16). In short, not only does Lenard not have a definitive biography, but he offers no authoritative autobiography either.

\section{Self-Translation And Autobiographical Deceit}

Among modern autobiographers a certain resistance to authorial authority is quite common, but Lenard goes a step further when he associates autobiography not with fiction and imagination, but with deceit and fraud. Discussing Goethe's autobiography, Lenard leaves open the possibility of an "honest" autobiographical lie. He writes: "Goethe lied honestly: Autobiography - Truth and Fiction Relating to my Life is the title of his book" [Goethe igen becsületesen hazudott: 'Életemböl - költészet és valóság' könyvének címe] (1973, One Day: 461). In his own case, however, Lenard leaves no room for fiction and imagination: his memoir is either true or it is a lie. For example, when editors asked him for a traditional biographical blurb, Lenard offered the following parodistic alternative:

The author of this book has never been to Brazil, and he is not a doctor... L.S. is his pseudonym. The book was written in the prison of Vác, where the author faces multiple fraud charges. Before serving time, the author sold ice cream in Rome and was an assistant pharmacist in Guatemala. The book is based on those experiences and on his imagination (1966/4/29).

[A könyv szerzöje sohasem járt Braziliában, nem is orvos ... L.S. (sic) az álneve. A könyv a váci fegyházban készült, ahol a szerzö jelenleg többrendbeli csalás miatt ül. Elözöleg viszont Rómában fagylaltot árult es Guatemalában patikussegéd volt. Ottani élményeiböl s képzelete termékeiböl irta e könyvet.] 
Lénárt-Cheng, Helga. "A Multilingual Monologue: Alexander Lenard's Self-Translated Autobiography in Three Languages." Hungarian Cultural Studies. e-Journal of the American Hungarian Educators Association, Volume 7 (2014): http://ahea.pitt.edu DOI: 10.5195/ahea.2014.3

Note that the description distorts the elements of Lenard's life only slightly, so that they remain recognizable, but false (Lenard did live in Rome but he did not sell ice cream, he did work as an apothecary but not in Guatemala, etc.) The blurb thus undermines Lenard's authorial identity by mocking the criteria of authority itself: What are the criteria of biographical authenticity? Is there such a thing as an innocent autobiographical lie? How do we know whether a distortion is intentional or not? Where does self-deception end and where does autobiographical fraud begin? Furthermore, the text depicts the author as a cheat and an impostor, which implies that his memoir might be a fraud, too.

The question of autobiographical deceit comes up again when Lenard decides to selftranslate his own autobiography. To self-translate one's own memoir is a most unusual decision, which is why there are no more than a handful cases of it in the history of literature. Yet, Lenard rewrote The Valley of the Latin Bear three times, in three different languages: first in German, then in English, and finally in Hungarian. Lenard penned the first complete version of this selfportrait in 1960 in Brazil. This first text was written in German, but it was based on earlier letters and published fragments, some of them Hungarian, others German. The text was published in installments in 1962 in the Stuttgarter Zeitung, followed by a book edition by the Deutsche Verlags-Anstalt in 1963. In 1965, Lenard added a few new episodes, and the final German version appeared under the title Die Kuh auf dem Bast [The Cow on the Pasture] (for details about the German texts see Kromar, for details about Lenard's enigmatic German title see Hassler). In the same year, Lenard translated the text into English and had it published in New York with a foreword by Robert Graves. The title of the English version, The Valley of the Latin Bear, is a reference to Lenard's highly successful Latin translation of Winnie the Pooh. Finally, a few years later a friend from Hungary, Klára Szerb, the widow of the writer Antal Szerb, urged Lenard to rewrite the text in Hungarian. Lenard agreed to "re-Hungarianize" the German and English versions of what had been mostly Hungarian memories in the first place, and the first Hungarian edition appeared in 1967 under the title Völgy a világ végén [Valley at the End of the World] (see below for further discussion of titles.)

Publishing his memoirs in three languages was an unconventional idea, but what made Lenard's decision truly audacious was to publish these three texts under different names and titles. On the German cover his name appears as "Alexander Lenard," the title of the book is Die Kuh auf dem Bast [A Cow on the Pasture], and the subtitle Aus den Erinnerungen eines Arztes [From the Memories of a Doctor]. The English edition shows the author's name as "Alexander Lenard," the title as The Valley of the Latin Bear, and the subtitle as "Life in a Remote Brazilian Valley-The Delightful Recollections of the Doctor Who Created Winnie Ille Pu." Finally, the Hungarian editions bear the name "Lénárd Sándor" (or "Lénard Sándor"), and the title Völgy a világ végén [Valley at the End of the World]. These differences are significant because the three covers offer absolutely no clues as to the origin of these texts; that is, there is no sign of these books being self-translations of the same text. Even the usual note "translated by the author" is missing, so readers of each edition would assume that they are reading an "original." The case of the first Hungarian edition, which listed the author's name as "Alexander Lenard," illustrates well the potential misunderstandings that these differences could cause, for seeing the nonHungarian name on the cover, Hungarian readers first assumed that "Alexander Lenard" was a foreigner, and that the text was a translation (see Kardos). This error greatly upset Lenard, because he wanted each audience to identify him as an author from their own literary tradition, so he made sure that subsequent Hungarian publications listed his name as "Lénárd Sándor." 
Lénárt-Cheng, Helga. "A Multilingual Monologue: Alexander Lenard's Self-Translated Autobiography in Three Languages." Hungarian Cultural Studies. e-Journal of the American Hungarian Educators Association, Volume 7 (2014): http://ahea.pitt.edu DOI: 10.5195/ahea.2014.3

One could argue that the decision to translate his own name was simply a manifestation of Lenard's commitment towards his new audience, that Lenard adapted his proper name to the phonetic and cultural environment of each target language in order to make it more accessible to target audiences. ${ }^{3}$ Indeed, as a self-translator Lenard made a whole series of textual and paratextual decisions that accommodated the linguistic and cultural expectations of his target audiences. Yet, one cannot miss the sarcasm in Lenard's remarks when it comes to the traditional, authoritative, monolingual use of proper names. As a self-confessed anarchist, Lenard resisted the convenience of easy identification. As he put it, "dictators enslave their victims with chains of paper. I inscribed my name on no list and in no registry of tenants, took my expired passport to no consulate ..." (1965: 19). This freedom had its price, of course, and it contributed to several misidentifications, such as the Mengele-case in 1968, when a journalist accused Lenard of being Mengele, the notorious Nazi doctor, and authorities raided his house in his absence.

Lenard rejected the naming conventions as an author, too, and he played name tricks like publishing his work in Latin as "Alexander Lenardus," in Italian as "Alessandro Lenard", "Zio Alessandro" and "Prof. Lenard." To add to the name confusion, out of financial need Lenard also sometimes allowed others to publish his work under their own name, as when a colleague from Switzerland paid Lenard to write medical articles, which he published under his own name, and Lenard also admitted to having written an entire medical journal using ten different pseudonyms (1965b/10/1). Finally, it also happened that his own writing was attributed to someone else, as for example in the case of his Latin translation of Max and Moritz, which appeared under the name of Gulielmus Groesswang (see Siklós). All this suggests that Lenard was not simply "localizing" his name to make it more accessible to target audiences, but that he was consciously challenging the authority associated with proper names. He even considered the potential legal consequences of his unorthodox name usage and self-translation. When the idea of selftranslating his German autobiography into Hungarian first arose, he began to contemplate the possibility of self-plagiarism. In a letter to a Hungarian friend he wrote: "What will the Deutsche Verlagsanstalt [the German editor] say? That I plagiarized myself? That I sold the same book twice?" [Mit szól majd a Deutsche Verlagsanstalt? Önmagamat plagializáltam? Kétszer adtam el ugyanazt a könyvet?] (1966/1/22). Lenard's sarcastic comment is effective because it reveals the absurdity of the question: how similar would Lenard's autobiographical personae have to be for his self-translations to seem like plagiarism, or, to put it differently, how different would they have to be for it not to count as plagiarism?

\section{Are Lenard's Self-Translations Adaptations or New Books?}

Selling "the same book twice" would of course qualify as self-plagiarism, but even Lenard hesitated about the status of his self-translations: were they really versions of the "same

\footnotetext{
${ }^{3}$ When discussing translation strategies, critics often distinguish between two objectives: "target-oriented" and "source-oriented." According to Gideon Toury (1995), the aim of a target-oriented translator is to create something highly readable and useable in the receiving culture, while a source-oriented translator aims for the maximum preservation of the source text's original, distinguishing features. Of course these two objectives do not mutually exclude each other, but when studying the strategies of a particular translator in a particular text, it is possible to confirm the dominance of one or the other.
} 
Lénárt-Cheng, Helga. "A Multilingual Monologue: Alexander Lenard's Self-Translated Autobiography in Three Languages." Hungarian Cultural Studies. e-Journal of the American Hungarian Educators Association, Volume 7 (2014): http://ahea.pitt.edu DOI: 10.5195/ahea.2014.3

book" or were they new books? In his private letters Lenard often referred to his self-translations as "translations." For example: "I have decided to quickly... translate my cows into Hungarian" [Most elhatároztam, hogy gyorsan ... magyarra fordítom a teheneimet] (1966/4/4); "I have translated exactly one quarter of The Cow" [A tehénnek pontosan egynegyedét forditottam le] (1966/4/21), etc. At the same time, he wondered about the difference between "rewriting" and "translating" and kept repositioning the borderline between them. To a friend he wrote: "By the way, I wonder what The Cow would be like in Hungarian. I will surely have to rewrite the textat least as much as I did with the English text" [Különben most arra gondolok, milyen lenne a Kuh Auf magyarul! Annyi biztos, hogy legalább annyira át kell írnom, mint az angol változatot] (1965b/9/2); "One thing is sure: The Cow cannot be translated, only rewritten" [Az biztos, hogy lefordítani nem lehet a Kuh-t, csak újra írni] (1966/Jan-Feb); "It would be easy to rewrite the text (the English version, too, is an adaptation rather than a translation)" [Könnyü volna a könyvet átdolgozni (angol verzióm is átdolgozás, nem fordítás] (1966/1/22). And as the manuscript neared completion, he concluded: "Towards the end it's no longer a translation, it's a new book!" [A vége felé már egyáltalán nem fordítás, hanem új könyv!] (1966/5/15).

If Lenard could call his translations "new books" it is because he was a committed targetoriented translator, who cared more about accessibility than adequacy; that is, instead of trying to preserve the source text's original features he adapted his texts to the needs and expectations of his new audience. Lenard used all five categories of translation processes analyzed by ancient rhetoricians (deletions, additions, permutations, substitutions, and repetitions) to maximize the readability of his target texts, which resulted in three new books, or at least in the illusion of three "new books." Following are two examples of target-oriented decisions made by Lenard in his translations, a cultural and a formal substitution, which demonstrate how far he went in adapting his text to the needs of his audience. Throughout the texts Lenard employs various modes of substitution (cultural and formal), with various objectives (domestication and exoticization of the text), and between various languages. The first example below involves Lenard's presentation of a local Brazilian artist about whose life not much was known, so to better explain the background to his German readers, Lenard compares this little-known Brazilian author to Homer and to an anonymous author from the German literary tradition: "we know even less about Homeros or the author of the Niebelungenlied" (202). In the English and Hungarian texts he preserves the reference to Homer, but he substitutes the "author of the Niebelungenlied" with other anonymous authors, thereby domesticating the reference: in English he compares it to the "life of the actor Shakespeare" (1965: 133), in Hungarian to "the scribe of King Béla" (1973, Valley, 117). The second example is that of a formal substitution. The formal substitution of linguistic source text elements always requires exceptional skills, and Lenard's linguistic brilliance shines here brighter than anywhere else. In this particular example Lenard needs to translate a key word of his Brazilian community, the Portuguese word capim ['to weed']. His solution is to substitute it in all three texts with a word of his own creation, which reflects both the formal properties of the original source text element and the phonetic environment of the target text: in German he creates kapinen, in English to capeen, and in Hungarian kapinálni. The linguistic bravura ends up being most effective in Hungarian, where the newly created word is very close both in form and meaning to the actual Hungarian word meaning 'to weed' ['kapálni'].

Lenard's use of substitution is particularly significant, because in his self-translation he goes a step beyond the objective of "transparency" and he purposely conceals the existence of his German source text. Substitution is known to reduce the target text's translation-effect more 
Lénárt-Cheng, Helga. "A Multilingual Monologue: Alexander Lenard's Self-Translated Autobiography in Three Languages." Hungarian Cultural Studies. e-Journal of the American Hungarian Educators Association, Volume 7 (2014): http://ahea.pitt.edu DOI: 10.5195/ahea.2014.3

than any of the other translation relations. Furthermore, substitution conceals not only the foreign origin of the substituted element, but it can also conceal the operation of substitution itself. This is the case in the following passage, where Lenard "quotes" from the yearbook of the local Brazilian-German community, written in the local dialect, Katherinendeutsch. He introduces his "transcription" with the following words (1965: 101):

\begin{tabular}{|c|c|}
\hline $\begin{array}{l}\text { Ich habe sie glattgestrichen } \\
\text { und gelesen und will, soviel } \\
\text { ich kann, ehrfurchtsvoll } \\
\text { abschreiben, ohne einen }\end{array}$ & $\begin{array}{l}\text { I have dusted them and read } \\
\text { them respectfully, and I will } \\
\text { copy a few pages, without } \\
\text { changing a single letter: }\end{array}$ \\
\hline
\end{tabular}

Szépen leporolom a lapokat, híven és saját hangnemükben próbálom lefordítani az írásokat:

Note that only in Hungarian does Lenard suggest that he will actually "translate" these texts. In German and English he uses the word abschreiben ['to copy'] and copy, and promises "not to change a single letter." What follows, however, is not a copy but a translation, as Lenard goes on to substitute the original Brazilian-German units with linguistic units from literary German, English, and Hungarian.

\begin{tabular}{|l|l|l|}
\hline $\begin{array}{l}\text { Am 12. Mai 1922 kamen } \\
\text { wir mit noch einer anderen } \\
\text { Familie in Donna Irma an. }\end{array}$ & $\begin{array}{l}\text { We arrived, together with } \\
\text { another family on May } \\
12 \text { th, 1922. }\end{array}$ & $\begin{array}{l}\text { Ezerkilencszázhuszonkettő } \\
\text { május tizenkettedikén } \\
\text { jöttünk Donna Irmába, mi és } \\
\text { még egy család. }\end{array}$ \\
\hline $\begin{array}{l}\text { Tage vorher hatte es viel } \\
\text { geregnet, und die Straßen } \\
\text { waren voll Schlamm und } \\
\begin{array}{l}\text { Löcher und darum war das } \\
\text { Fahren auf dem Wagen kein } \\
\text { Vergnügen. }\end{array}\end{array}$ & $\begin{array}{l}\text { It had rained a great deal the } \\
\text { day before, the roads were } \\
\text { full of mud and holes; } \\
\text { riding a carriage was no } \\
\text { pleasure. }\end{array}$ & $\begin{array}{l}\text { Elózö nap esett, nem volt } \\
\text { pocsot a sáros úton, a mély } \\
\text { keresztülver }\end{array}$ \\
\hline
\end{tabular}

Lenard's promise about transcribing the original "without changing a letter" is a perfect example of how substitution can mask the process of translation by letting analogy produce the illusion of originality, and it shows how Lenard took full advantage of substitution to create the illusion of "new books."

\section{The Authority of a Proper Name vs. a Pseudonym}

To return to the question of self-plagiarism, the problem in Lenard's case was not that his target-oriented practices resulted in "new books," but that he multiplied his authorial identities as well, and together, these two practices led to a highly unusual situation where we have three different memoirs with different titles and (at least seemingly) different authors. That is, the word "self-plagiarism" acquires in Lenard's case a double meaning, implying both that the author plagiarizes his own text and that he plagiarizes his own self. The genre of the selftranslated text matters here a great deal, for two reasons. First, autobiographies symbolize more than any other genre the expectation that there be a representative relation between the lived and the written life story of the author. This expectation dictates that there should only be one version of a life story, although autobiographers may write several narratives that treat different periods or aspects of their lives. The appeal of this idea of a "definitive autobiography" is surprisingly 
Lénárt-Cheng, Helga. "A Multilingual Monologue: Alexander Lenard's Self-Translated Autobiography in Three Languages." Hungarian Cultural Studies. e-Journal of the American Hungarian Educators Association, Volume 7 (2014): http://ahea.pitt.edu DOI: 10.5195/ahea.2014.3

persistent even in our postmodern age, which is why Lenard's decision to "re-write" his life story three times constitutes such a provocative act. Second, autobiographies depend more than any other genre on the authorizing function of the proper name, for a publicly verifiable name is considered a precondition of the authenticity of any autobiographical narrative. The author's proper name gained particular importance in the 1970s as critics tried to locate the key to autobiographical identity in the text itself, rather than outside of it. According to Philippe Lejeune, one of the most famous theoreticians of the genre, what guarantees the "autobiographical pact" between author and reader is not some obscure notion of autobiographical "truth" but rather the triple identity between the name of the main character, the narrator, and the author. By focusing on this strictly textual and paratextual criterion of a formal correspondence between names, Lejeune has elegantly neutralized the messy question of extratextual autobiographical reference. However, he neglected to clarify what exactly he meant by the authorizing function of proper name: is it based on the authority of the name in the author's birth certificate, or on the authority of the author's previously published works, or does it reside perhaps in the authority of the author's signature ${ }^{4}$ Lenard himself was skeptical about all of these possibilities: as an anarchist he opposed the act of inscribing names into official registers; as an illegal immigrant he knew what it meant to be denied the "property" rights of a proper name; and as a newly published author he was conscious of the fact that his name and signature carried little weight, for the publication of his autobiography preceded the publication of his other works, which meant that most of his readers would not have been able to identify his name on the cover.

Interestingly, instead of trying to compensate for his lack of authority, Lenard further weakened the authority of his proper name by declaring that "A.L. (sic) is his pseudonym" [L.S. (sic) az álneve] (1966/4/29). This tongue-in-cheek remark exposes again the naïve notion of the absolute ownership of one's proper name: we have no single name that could guarantee the authenticity of our multiple narratives because all versions of our names are only pseudonyms. With this playfully worded but audacious declaration Lenard anticipated postmodern theories on the paradoxical nature of proper names. According to these theories, the paradox of the proper name consists in the fact that it is both absolutely "proper" (hence singular, untranslatable, and unique) and generally recognizable (hence translatable and repeatable). This paradox implies that neither the proper name, nor the author's signature, can ever fulfill their referential functions, because they both depend on others' a posteriori repetitions and validations to guarantee the author's identity.

Lenard shares postmodern theorists' view about the split nature of proper names and in his autobiography he mocks our futile attempts to try to claim proper names as belonging to only one single "owner." In one section he discusses the naming conventions in Brazil and notes that it often surprises Europeans to see all the Napoleons, Beethovens, and Euclids' among the indios and settlers. "The result is somewhat embarrassing for one who has a certain concept in mind when he speaks the names of Beethoven and Hippocrates. For the colonist they are just names, and he likes them" (1965: 57) [Az európai, aki Beethovennel vagy Hippokratésszel még egy

${ }^{4}$ Later Lejeune refined his notion of the "autobiographical space," see for example Lejeune: Pour l'autobiographie (1998). 
Lénárt-Cheng, Helga. "A Multilingual Monologue: Alexander Lenard's Self-Translated Autobiography in Three Languages." Hungarian Cultural Studies. e-Journal of the American Hungarian Educators Association, Volume 7 (2014): http://ahea.pitt.edu DOI: 10.5195/ahea.2014.3

bizonyos fogalmat társít, sokszor csodálkozik. A bennszülött részére már csak nevek, mint Jancsi vagy Pali] (1973, Valley: 53). It seems that in this Brazilian valley proper names, just like common nouns, can fade and gain renewed meaning at each application, so that no single user counts as more "original" than the others. Lenard relates for example how his barber wears the name "Perikles" without ever wondering to whom this name "originally" belonged. A misspelling can make this process of renewal even more pronounced, as for example in the case of "Nebson" instead of "Nelson." Lenard notes: "And if the calendar had a typo, that was no problem either, Nelson is not any better than Nebson. The little boy next door on the right was named Edilson, and he still wears that name" [És ha a naptárban sajtóhiba volt, nem baj, Nebson se rosszabb, mint Nelson. A jobb oldali házban született kisfiút Edilsonnak nevezték, és az is maradt] (1973, Valley: 53). Similarly, in the long chain of "owners" reaching back towards the past there is no first "Rubens." The "Rubens" at the Brazilian gas station is as rightful an owner of his name as the famous painter. Lenard remarks with humor: "The son of the tailor from across the church is called Rubens. 'How did you find this name?'-I ask the mother. 'I named him after the gas station owner in Joacaba'—-she replies" [A templommal szemben lakó szabó fia Rubens. „Hogy jutott ehhez a névhez?”-—érdem az anyját. „A joacabai benzinkút tulajdonosa után neveztem"-feleli] (1973, Valley: 53).

Lenard views his own proper name with a similar irreverence, and he questions whether there is an "original" Alexander Lenard in the series of his translated names. It is not by chance that Lenard - just like the French critic Jacques Derrida — uses the genre of autobiography to demonstrate the paradox of the proper name, and that they both formulate it as a question of translatability (Derrida 1988). The question of translatability, that is the question whether various versions of the same thing correpond to each other, assumes that there exists a meta-language, a tertium comparationis that would allow us to compare A to B. Lenard, like Derrida, rejects this idea of a third reality. To him "Alexander Lenard" just like "Lénárd Sándor" or any of his other names are "only" pseudonyms in the sense that they only refer to each other and to the texts. There exists no meta-Alexander Lenard who, as an extra-textual entity, could guarantee that Alexander Lenard, Lénárd Sándor and all the others are one and the same person. And since in the word pseudonym 'pseudo' means both "deceptively similar" and "fraudulent," Lenard's statement according to which "A.L. is his pseudonym" returns us again to the question of autobiographical fraud. This time, however, the question is not whether the autobiographer lies or not, but why we continue to believe in the authority of the proper name when every autobiographer, without exeption, commits fraud simply by signing the story as his or her own.

\section{Conclusion}

I have tried to show in this essay how Lenard used self-translation to challenge certain protocols associated with life-writing, but of course the very decision to self-translate a memoir was a superb provocation in itself. There have been other attempts at autobiographical selftranslation: Julien Green's, Leila Abouzeid's and Vladimir Nabokov's experiments have all been well documented, but the list of self-translated memoirs is still rather short. Nabokov seems to have been well aware of the unprecedented nature of his enterprise. In his celebrated memoir, Speak Memory, he claims to have been the first to go through multilingual autobiographical metamorphoses: "This re-Englishing of a Russian re-version of what had been an English retelling of Russian memories in the first place, proved to be a diabolical task, but some consolation was given me by the thought that such multiple metamorphosis, familiar to butterflies, had not been tried by any human before" (Nabokov 12-13). While Nabokov may 
have exaggerated a bit, it is true that there are not many self-translated memoirs, and until recently critics have largely neglected the phenomenon. Today, however, as more and more translingual writers challenge the borders of national literary canons, critics are finally beginning to question the practical, theoretical, and political implications of self-translation. One important result is that self-translation is no longer seen as a special subcategory of translation, but critics see it as paradigmatic of how all translation exposes the dependence of the translated text on the translation. Moreover, the notion of self-translation has also been metaphorically extended to encompass the entire self-reflexive process of identity formation, and self-translation understood more generally as the "translation of self" is a central topic in many recent cross-cultural autobiographies and their studies. This has pushed the genre of autobiography into the foreground, as critics focus increasingly on the interplay of self and textuality in self-translated memoirs.

In spite of these recent developments in the study of self-translation, existing theories of self-translation cannot be applied to Lenard's texts, for several reasons. First, since most selftranslators are "only" bilingual, theories of self-translation tend to operate with the binary terms "native tongue" and "adoptive tongue." These terms, however, do not fit the polyglot Lenard's situation, partly because he self-translated into more than two languages, and partly because he did not have a single "native" tongue. Second, Lenard's case defeats standard analysis because of the multi-directionality of his translation processes. Self-translation mostly occurs in the context of trans-lingual stories of immigration, so theorists tend to use one-directional models to describe it (such as "transition" or "adoption"). However, Lenard's relation to his languages and cultures was much more unsystematic and multi-directional, and he remained an outsider in all three of his target languages and cultures.

Future studies of Lenard's self-translation should therefore focus on the circularity and interdependence of Lenard's three self-translated texts. The method called "stereoscopic reading" - developed by Marilyn Gaddis Rose (1997) — could be particularly fruitful in studying the intersection of Lenard's discourses. "Stereoscopic reading" involves reading a text alongside its translation so that the reading can be grounded in several worlds of meaning simultaneously. According to Gaddis Rose, such a reading allows us to focus on the rich interliminal space formed by overlapping texts, because the boundaries of translated phrases and sentences become thresholds rather than barriers. In The Bilingual Text, Jan Wash Hokenson and Marcella Munson apply this concept of "stereoscopic reading" to self-translation and show how this method can disclose the intertextual surplus of self-translated works as well:

The bilingual text, from its two sides, directly opens out on that space, the interliminal region between languages, disclosing residues of the social and intellectual history that both systems now exhibit, in virtual overlap and intersection, through bilinguality. The single voice of standard second-hand translation silences that space. Intercultural self-translation constructs it stereoscopically as a unique reading field (Hokenson, Munson 12).

Such a stereoscopic (or rather multiscopic) reading of Lenard's three texts would have the advantage of illuminating the extent to which Lenard ses himself as constructed through language, while also enriching the theory of self-translation with a unique case study. 


\section{Works Cited}

Besemeres, Mary. 2002. Translating One's Self: Language and Selfhood in Cross-Cultural Autobiography. Oxford: Peter Lang.

Cordingley, Anthony, ed. 2013. Self-Translation: Brokering Originality in Hybrid Culture. London: Bloomsbury Publishing.

Courtivron, Isabelle de, ed. 2003. Lives in Translation: Bilingual Writers on Identity and Creativity. New York: Palgrave Macmillan.

Derrida, Jacques. 1988. The Ear of the Other: Otobiography, Transference, Translation. Lincoln: University of Nebraska Press.

Gaddis Rose, Marilyn. 1997. Translation and Literary Criticism: Translation As Analysis. Translation Theories Explained Series. Vol. 6. Manchester: St. Jerome Publishing.

Green, Julien. 1987. Le Language et son double ['The Language and Its Shadow']. Bilingual edition. Translated by Julien Green. Paris: Seuil.

Hassler, Otto. 2008. "Brasilien: Blaukraut-Marsch auf Sägemehl” ['Brazil: Red Cabbage-March on Sawdust'] In Landeskunde. Conhecendo o Brasil. http://www.topicos.de/fileadmin/pdf/12008/hassler.pdf

Hokenson, Jan Walsh and Marcella Munson. 2007. The Bilingual Text: History and Theory of Literary Self-Translation. Manchester: St. Jerome Publishing.

Kardos, G. György. 1973. "Ember a világ végén" ['A Human Being at the End of the World']. Introduction to Völgy a világ végén s más történetek ['Valley at the End of the World and Other Stories']. Budapest: Magvetö Kiadó.

Kromár, Pál. 2002. "Lénárd völgye" ['Lenard's Valley']. Élet és Irodalom, XLVI/45, November $8,2002$.

Lenard, Alexander. 1957. "Három modern magyar lovag kalandjai" ['The Adventures of Three Hungarian Modern Knights']. Irodalmi Újság, Paris, 1957. Oct. 1. http://mek.oszk.hu/kiallitas/lenard/irasok/cikkek/3lovag.html

- 1963. Die Kuh auf dem Bast: Aus den Erinnerungen eines Artztes ['The Cow on the Pasture: From the Memories of a Doctor']. Stuttgart: Deutsche Verlags-Anstalt.

- 1965. The Valley of the Latin Bear. Foreword by Robert Graves. New York: E. P. Dutton \& Co. Inc.

— 1965b. Lenard letters. ${ }^{\text {st }}$ box. V. 5415/397/1-45. Lenard Archives. Petőfi Irodalmi Múzeum [Petöfi Literary Museum], Budapest. Manuscript.

- 1966. Lenard letters. $2^{\text {nd }}$ box. 2. V. 5415/397/46-151. Lenard Archives. Petőfi Irodalmi Múzeum [Petőfi Literary Museum], Budapest. Manuscript.

—. 1967. Völgy a világ végén ['Valley at the End of the World']. Budapest: Magvetö Könyvkiadó.

—. 1973. Völgy a világ végén s más történetek ['Valley at the End of the World and Other Stories']. Budapest: Magvető Könyvkiadó.

—. 2013. Stories of Rome ['Római történetek 1969']. Translated by Mark Baczoni. Budapest: Corvina.

Lejeune, Philippe. 1975. Le pacte autobiographique ['The Autobiographical Pact']. Paris: Seuil. Nabokov, Vladimir. 1967. Speak Memory: An Autobiography Revisited. New York: Vintage International. 
Lénárt-Cheng, Helga. “A Multilingual Monologue: Alexander Lenard’s Self-Translated Autobiography in Three Languages." Hungarian Cultural Studies. e-Journal of the American Hungarian Educators Association, Volume 7 (2014): http://ahea.pitt.edu DOI: 10.5195/ahea.2014.3

Oustinoff, Michaël. 2001. Bilinguisme d'écriture et auto-traduction: Julien Green, Samuel Beckett, Vladimir Nabokov ['Bilingual Writing and Self-Translation: Julien Green, Samuel Beckett, Vladimir Nabokov']. Paris: L'Harmattan.

Siklós, Péter. "A Max und Moritz latin fordításának története” ['The history of the translation of the Latin Max und Moritz']. March 6, 2002. http://mek.oszk.hu/kiallitas/lenard/szeminarium/irasok/latmax.html.

Toury, Gideon. 1995. "The Nature and Role of Norms in Translation." Descriptive Translation Studies and Beyond. Amsterdam-Philadelphia: John Benjamins, 53-69. 